\title{
Unmasking of the President Joko Widodo's Ideolgy Stances Realized in His Political Speech towards the People of Indonesia.
}

\author{
Suswanto Ismadi Megah S. ${ }^{1}$ \\ megah76@yahoo.co.id \\ Siti Noor Mohd. Noor ${ }^{2}$ \\ Azmi Abdul Latif ${ }^{3}$ \\ ${ }^{123}$ University Tun Hussein Onn, Malayisa
}

\begin{abstract}
This paper aims to unmask President Joko Widodo (Jokowi, henceforth)' ideology through his presidential speech. Using a combination of CDA and SFL as an analytical tool of appraisal system, particularly the subsystem of attitude to dismantle ideological stances behind the speech text toward the People of Indonesia. The data was obtained from the first state speech of Jokowi in 2015. Further, selecting the first state speech was the parameter of his leadership in ruling the nation. The results show that Jokowi employed all subtypes of attitude to the people of Indonesia. The subtype of Judgment mostly with positively-invoked capacity employed by Jokowi indicates that He has an ideological inclination to judge the people's character as the capable people who can overcome the worst condition. Therefore, Jokowi implicitly shows his ideological inclination toward the people that he inclination to prioritize the Indonesian people.
\end{abstract}

Keywords: Ideology, Political speech, Jokowi, and people of Indonesia

\section{INTRODUCTION}

In the last decades, Indonesia has practiced a democratic country after more than three decades of experienced banned political participation (Santoso, 202; Agustino \& Agus Yusoff, 2014; Santosa et al., 2014; Komara, 2015). After the resignation of President Soeharto Indonesian people experienced euphoria to channel their political desire. This time political freedom has produced various kinds of political discourse. It emerges politicians more freely build their political expression. Politicians deliver political intentions to get their political goals logically and emotionally to push the people to follow them (Abdulameer, 2019). This political expression has produced freer political discursive speech (Bayram, 2010; Santosa et al., 2014; Sharndama, 2015). To realize political intention through language is considered more effective. Political speeches are employed by some nation leaders to manifest their political goal by disseminating ideology inserted political speech texts, for instance, a President as a nation and political leader normally deliver their political goal through speech. The speech is a manifestation of the spoken text read to influence people directly or indirectly.

Speech is normally employing language as a medium realized via text, whereas the text is influenced by a context (Halliday \& Matthiessen, 2014). The context which influences text is related to the text users, for instance for political purposes. Thus, language is used to express semiotic reality which is a relationship with text and context (Martin,1992; Halliday \& Matthiessen, 2004). Thus, language is a crucial medium used in political speeches for the president to impart their ideas, thoughts, programs, policies, etc. In line with (Brognolli,1998; Latupeirissa, 2019) language is a medium to arise a certain political goal for the president to make people understand what they deliver via political language. Through language political speech is a way to open and widen hidden 
ideology (Mustafa, 2014). Besides, (Abdulameer, 2019) observed recently all politicians include the president have attempted to influence the people through political speech as an effective way to make the people influenced by the speeches conveyed in terms of presidential speeches' texts, these affect a great impact and which also disseminate and mystify ideological contents when one listens or reads the texts. Those results to find the ideological stance inside the texts, which pushes it to make policies in a period of his national service. In this situation, a president may manipulate and use language to result in hegemony in the society.

Political speech is an important medium to send ideas, thoughts, wants, and ideology. The text which is sed by an influenced person will give a great impact on people and the world due to it makes a policy recognized either nationally or internationally (Mustafa, 2015; Abdulameer, 2019). when a person says or writes, they produce text (Halliday \& Matthiessen, 2004, 2014).

Political speeches are media for presidents in Indonesia after the fall of Soeharto to attract the people as the main purpose since the fall of Soeharto Indonesian President is voted directly by the people. Therefore, the people of Indonesia are the main social actor should be inserted in the presidential speech texts. People are the main social actor mostly used by Indonesian presidents to show their alignment toward the people who have supported them in the presidential election. It is similar to President Joko Widodo has, the grassroots or known as the term of wong cilik who is the basic political party that has supported Jokowi to be president.

To find the gap in this current paper, prior researches of the Indonesian presidents had been conducted by some researchers. By using Critical Discourse Analysis (CDA) and Systemic Functional Linguistics (SFL) to see how language and power are bounded in a text to investigate power abuse and ideology used in the text. Kusumaningrum (2014) CDA incorporates with SFL to see the ideological stance of President Yudhoyono (SBY) through his political speech text.
Suharto (2016) examined the Political language of the presidential speech texts of President SBY. Then Rangga (2016) studied President Jokowi's ideology through his political speech. He applied van Dijk's critical discourse analysis to unmask Jokwois' intentional ideology inserted in the state of Jokowi's ideology. This paper has the objective to reveal the hidden ideology of Jokowi realized how he evaluates the people of Indonesia to identify his political direction via the appraisal analysis system of Martin (1992), Martin and White (2005), Noor (2015), particularly the subsystem of attitude is the correct way as the framework rather than two other subsystems (Alsanafi, 2018, 2019).

This paper reviewed applied systemic Functional Linguistics (SFL) theory since language cannot be separated from the social function by Halliday and Hasan (1976). He introduced Systemic Functional Linguistics (SFL) with three systems of meaning, known as metafunction which consists of ideational, interpersonal, and textual metafunctions. On the other hand, [24] focuses on investigating text structure to explore power and ideologies. Noor (2015) channels the CDA of Fairclough and incorporates SFL in doing CDA to analyze text structure. This study employs an analytical tool of the appraisal aspect of SFL to explore the ideological inclination of Jokowi.

Appraisal Analysis is obtained from SFL Systemic Functional Linguistics (SFL), in terms of interpersonal meaning (Martin, 1992; Alsanafi et al., 2019a, 2019b). Appraisal has three subsystems; Attitude, engagement, and graduation. Attitude deals with feelings, including emotional reactions, judgments of behavior, and evaluation of things"( martin, 1992). Attitude is viewed as the most applied and crucial subsystem within Appraisal Analytical Theory (Alsanafi, 2020). Attitude has three components as the sub-systems which are: Affect, it concerns with emotion which consists of un/happiness, in/security, dis/satisfaction. And dis/inclination (Alsanafi, 2019b). While, Judgement indicates the evaluation of human characters which consists of tenacity, capacity, normality, propriety, and veracity (Martin, 1992). Appreciation deals with the evaluation of things which consist of reaction, 
composition, and valuation (Martin, 1992; Alsanafi, 2019b).

\section{METHODOLOGY}

This paper employed a descriptive-qualitative research type. It is an amalgamation of qualitative and quantitative research to emphasizes the outcome of this paper. According to (Alsanafi, 2020) used both research types, qualitative and quantitative may arise more contributive-dynamic multiplicity research. besides descriptive qualitative research type is appropriately used to analyze the lexical utterance of the texts (Santosa, 2003; Santosa et al.,2014). The data set was obtained from one prominent presidential speech in the first year of Jokowi on the occasion of the Indonesian Independence Day. The data was retrieved officially from www.setkab.go.id

Data analytical procedure was done by using Fairclough's (1995) Critical Discourse Analysis within Systemic Functional Linguistics (SFL), particularly appraisal analysis of Martin and White (2005). This analysis is framed based on Fairclough CDA's model which consists of a. text description based on formal properties, interpretation of the text how text is produced and consumed, and socio-cultural analysis is to relate between discourse and society. on, and culture, where the text is being explained.

\section{RESULT AND DISCUSSION}

As already noted previously the Indonesian president after the fall of Soeharto is voted directly by the people of Indonesia. Therefore, how the president evaluates the people to disseminate his ideological stance to maintain and reach political power toward the people Thus, the people of Indonesia is the main social actor to be evaluated through the subsystem of attitude, particularly judgmental analysis.

As stated in the previous section that Attitude has three sub-systems, Judgment, and
Appreciation. That subsystem of attitude is used to explore the semiotic and linguistic units by examining all attitudinal utterances to study successively (Alsanafi, 2020). In this section, we focus on the selected data set from attitudinal items. The data findings are shown as in the results got are indicated in the form of quantity Numbers or Percentages and Tables, which cover all occurrences and portions correspondingly. To make all comparisons between all judgmental categories. This enables us to get a clear value of the ways how Jokowi appraises the people of Indonesia and what are the reasons Jokowi behind his lexical choices. The result shows that some quotations are taken from the speech texts with the description to draw the main intention of this study as can be seen in Table 1

\section{Table 1}

\begin{tabular}{lll}
\hline Kinds & Quantity & Percentage \\
\hline
\end{tabular}


LANGUAGE CIRCLE: Journal of Language and Literature, 15(2) April 2021

\begin{tabular}{lll}
\hline Affect & 8 & $1.3 \%$ \\
\hline Judgment & 27 & $51.2 \%$ \\
\hline Appreciation & 14 & $28.5 \%$ \\
\hline Total & 49 & $100 \%$ \\
\hline
\end{tabular}

It is clear as can be shown in Table 1 that significant results shows the judgment category has dominated applied rather than the other two attitudinal categories with large occurrences in his whole political speech text conveyed to evaluate the people of Indonesia. The total number of occurrences is 49 occurrences and the judgmental categories placed more than half of the total data found. It $5.2 \%$ of all the texts. Attitudinal propositions evaluated applying the appraisal subsystem of Judgement. The Table pinpoints the appreciation placed the second position after the judgment with a lace of analysis to almost 14 occurrences $(28.5 \%)$ of all Attitudinal analysis in the whole speech text. The effect is at the least position with only $8(16,3 \%)$ of the whole Attitudinal utterances employed by Jokowi. It is a more detailed description of attitudinal choices for each as the following examples.

(1) ... 300 thousand schools, and almost 40 million students, ... Appreciation

(2) ... we immediately responded, ... Judgment

(3) ... Let us together express our gratitude to God the Almighty ... Affect
The examples indicate how Jokowi evaluates the people of Indonesia through three subsystems of attitude, but as the data findings that judgment category is mostly preferred by Jokowi to appraise the People Indonesia, over the two other types of attitudes; (Affect and Appreciation). Referring to political speech, Jokowi disseminates his ideology realized by evaluating the people of Indonesia through lexical utterances. The judgmental category is mainly put as the main concern in the spreadsheet (Alsanafi, 2020). Jokowi judged the people of Indonesia via various types of judgmental categories to investigate the Indonesian people's behavior being appraised occurred more than half of the total number $(51.2 \%)$. It shows how Jokowi's inclination toward the people of Indonesia as the main priority in his government as he comes from a grassroots family. Besides political party which has brought to be the top leader in Indonesia is the people party is known as 'wong cilik'(the grassroots party) (Jaya, 2017). It is a more detailed explanation and description of how Jokowi evaluates the people of Indonesia using judgmental analysis as can be seen in Table 2.

Table 2

Judgmental Categories

\begin{tabular}{|c|c|c|}
\hline Kinds & Quantity & Percentage \\
\hline Tenacity & 6 & $22.2 \%$ \\
\hline Propriety & 7 & $25.9 \%$ \\
\hline Capacity & 11 & $23.4 \%$ \\
\hline Normality & 2 & $4.3 \%$ \\
\hline Veracity & 1 & $2.15 \%$ \\
\hline Total & 27 & $100 \%$ \\
\hline $\begin{array}{l}\text { As c } \\
\text { evaluates t } \\
\text { categories } \\
\text { using pos } \\
\text { Propriety p } \\
(25.9 \%) \text { Ca }\end{array}$ & $\begin{array}{l}\text { Table } 2 \text { that } \\
\text { ugh the jud } \\
\text { re Tenacity } 6 \\
\text { ed evaluatio } \\
\text { ed with a nun } \\
\text { hugest numbe }\end{array}$ & $\begin{array}{l}\text { positively-invoked evaluation. And then } \\
\text { Normality comes to } 2 \text { occurrences }(4.3 \%) \text { with } \\
\text { positively- inscribed evaluation. Whereas } \\
\text { veracity is the least occurrences with only } 1 \\
\text { occurrence }(2.15 \%) \text { by using negatively- } \\
\text { inscribed. }\end{array}$ \\
\hline
\end{tabular}

than the others with 11occurres (22.2\%) using 
It can be described that Jokowi mostly evaluates the people of Indonesia using positivelyinvoked Capacity, it can be interpreted how Jokowi has the most interest to evaluate toward the people of Indonesia as in his official speech and distributed to all audiences who watch or listen to the speech. It can indicate that how Jokowi evaluates the people of Indonesia as his main priority due to some reasons such as he is elected directly by the people of Indonesia, it is proper to prioritize them. Secondly, he is supported the party people-base. Thirdly, he comes from the ordinary people, not like most of the Indonesian presidents who come from the Javanese-Indonesian elites is a more detailed description and explanation can be seen in examples as follows.

... critical young voters who have strong motivation to safeguard the running of democracy and governance.

... In addition, currently, Indonesia also has a significant number of middle-class people...

As can be seen, Example 4 indicates that the people of Indonesia who are capable people as shown by 'young voters they have ,strong motivation'. 'The strong motivation' implicitly shows that they have the capability to uphold the democratic and good government. The judgmental category of the capacity conveyed by Jokowi indirectly to appraise the people of Indonesia. Therefore, the lexical choices of 'the strong motivation' indicate that the people of Indonesia who are represented as the young voters have the strength in terms of their motivation. This lexical choice is interpreted when Jokowi conveyed in Independence Day to all audiences who attend in the house of Parliament or via television live program at home. The use of invoked positive Capacity can be explained that Jokowi as the leader he appraised the people's work. Besides, as the honorable Javanese gentleman he cannot expose something directly.

Example no. 5 shows how the people of Indonesia are dominated by the middle class. The middle class can be described as the class which has an equal position in economic status. It can be interpreted that the middle class means that the people of Indonesia can do something significant to arise their economic position higher. It explains that Jokowi can make the people of Indonesia achieve a better position to arise the capability through his programs offered to the people. To sum, the way how Jokowi transfer ideological stance inserted the speech text using more indirectly and invoked rather than directly is motivated by two reasons. The first his sociological background of Jokowi as Javanese tends to say something more indirectly. As stated that the Javanese tend to express indirectly (Handayani, 2009). Second, his political background as the people base party (PDI-P, Struggle Indonesian Democratic Party) drives him to prioritize the people. Jokowi has an ideology inclination to be pro-the people (Jaya, 2017). The ideology is brought by Jokowi to align the people is to persuade the people that he is capable to make the people better life in order for the people to support him and to make easier handling his leadership.

\section{CONCLUSION}

This paper can be concluded as a detailed description and explanation of how Jokowi inserts his ideology through political speech text. By adopting the subtype of attitude, the Judgment category to make it possible to draw Jokowi's political position to rule the nation named Indonesia how he reaches and maintains his power by inserting his ideology through political speech. $\mathrm{He}$ is described as a grassroots leader who is closed to the people and has a commitment to make people prosperous. As the 'grassroots' or 'wong cilik's president, he shows how he concerns to prioritize the people as the main intention. He persuades people through his political speech that the people of Indonesia are the capable people who are able to achieve high achievement as he manifested in the political speech text that the middle class is rising. It shows the capability of the people to achieve a higher level of economic status.

Most occurrences of using the judgmental category show his motivation and ideological 
inclination inserted his presidential speech text toward the people of Indonesia. By using the judgmental category through positive invoked evaluation of Capacity indicate Jokowi's ideological inclination as depicted in his speech text. It proves that he is able to mystify the people to work hard to achieve their prosperity. Using mostly positive-invoked evaluation toward the people is influenced his social background as Javanese who tends to express his ideas more implicitly and directly. There are two main reasons behind his political speech. The first refers to the social background as Javanese who high consideration to say frankly or directly, he probes through invoked appraisal toward the people. Second, he is supported by people base party that has basic supporters from the 'grassroots' enables him to align the Indonesian people.

\section{REFERENCES}

Abdulameer, A. et al. (2019) Systemic Functional Linguistics of Political Article. Humanities E Social Sciences Review. Soc. Sci. Rev., 7(5), 24-31, 2019, doi: doi.org/10.18510/hssr.2019.753.

Agustino, L., \& Agus Yusoff, M. (2014) From new order to reformasi: Indonesian subnational politics in the post-new order era, J. Hub. Int., 3(1,), 13-24, 2014, doi: 10.18196/hi.2014.0042.13-24.

Alsanafi, I.H, Noor, S.N.F.M., \& Kadir, Z.A (2018) Development of black feminine identity in two postmodern American plays through appraisal framework: comparative study. Amaz. Investig., 8(21), 104-116, [Online]. Available:

https://www.amazoniainvestiga.info/index. php/amazonia/article/view/52.

Alsanafi, I.H, Noor, S.N.F.M., \& Kadir, Z.A (2019a). "Judgemental Category" is the major concept in Ntozake Shange"s "For colored girls who have considered suicide/when the rainbow is Enuf, Int. J. Eng. Adv. Technol., 9(1), 256-264, doi: 10.35940/ijeat.A1136.109119.
Alsanafi, I.H, Noor, S.N.F.M., \& Kadir, Z.A. (2019b). Examining the clarity of expressions in describing the black woman's oppression in kennedy's 'funnyhouse of a negro. Humanit. Soc. Sci. Rev., 7(5),. 63-70, 2019, doi: 10.18510/hssr.2019.758.

Alsanafi, I.H. (2020). The Quest for identity of African-American women from 1939 to 2000 in American drama, Doctoral Thesis Universiti Tun Hussein Onn.

Bayram, A. (2010). Ideology and political discourse: A critical discourse analysis of Erdogan's political speech. ARECLS, 7, 2340.

Brognolli, A. (1998). Language and ideology: A case study of 'Sesame Street'.

Fairclough, N. (1995). Critical discourse analysis: the critical study of language. Longman..

Halliday, M.A.K, \& Matthiessen, C. M. I. M. (2014), Halliday's introduction to functional grammar: Fourth edition.

Handayani, S. (2009) Unggah-Ungguh Dalam Etika Jawa, Skripsi Unggah-Ungguh Dalam Etika Jawa, p. 11.

Halliday, M.A.K., \& Hasan, R. (1976) Cohesion in English. Longman Group Limited.

Halliday, M.A.K., \& Matthiessen, C.I.M. (2004) An Introduction to Functional Grammar. Holder Arnold.

Halliday, M.A.K., \& Matthiessen, C.I.M. (2004). Halliday's Introduction to Functional Grammar. Holder Arnold.

Jaya, P.H.I. (2017). Distorsi komunkasi pemerintahan Presiden Jokowi di media social. IJurnal Imu Komun., 14, 259-276. doi: 10.14419/ijet.v7i3.27.17760.

Komara, E. (2015) Sistem politik Indonesia pasca reformasi, 2(2), 117-124. doi: 10.15408/sd.v2i2.2814.Permalink/DOI.

Kusumaningrum, Y, F. (2014). Analisis Kritiks Teks Pidato Susilo Bambang Yudhoyono 
Terkait Kenaikan BBM Tahun 2012-2013, Master Thesis Universitas Diponegoro, Semarang,

Latupeirissa, D.S. (2019). Revealing Ideology of Political Speech, 6(2).

Mustaf., (2014). A Critical Discourse Analysis of Global economy in Strategic Texts, University of Malaya, 2014.

Martin, J. R. (1992) English Text. John Benjamins.

Martin, J.R., \& White, P.R. (2005). The Language of Evaluation. Palgrave Macmillan.

Martin, J.R. (2014). Genre, ideology and intertextuality: A systemic functional perspective, 2 .

Newspapers. 2014. Kata, 16(1), 23-36, doi: 10.9744/kata.16.1.23-36.

Noor, S.F.N.M.(2015) “Empowering the Powerful: A Critical Discourse Analysis of Public Graduate Employability," Doctoral Thesis Macquire University, Australia.
Rangga, A. (2016). Strategi kebahasaan Jokowi dalam menanamkan Ideologi dan Manfesto Pemerintahan. Jurnal Litera, 15(2),. 379-388.

Santosa, R. (2003). Semiotika Sosial: Pandanagn terhadap Bahasa. JP Press.

Santosa et al. (2014). Register of antagonist's language in media: An appraisal study of Indonesian. Journal Kata.

Santoso, A. (2002). Penggunaan bahasa Indonesia dalam wacana politik, Universitas negeri Malang.

Sharndama, E.C. (2015). Political discourse: A critical discourse analysis of President Muhammadu Buhari's inaugral speech, J. Chem. Inf. Model., 3(3), 12-24.

Suharto, T. (2014). Bahasa politik dalam teks pidato Presiden Susilo Bambang Yudhoyono, [Online]. Available: http://repository.um.ac.id/64315/ 
